\title{
Intracoronary thrombolysis in acute myocardial infarction
}

\author{
NICHOLAS BROOKS \\ From the Cardiac Department, London Chest Hospital, London
}

An analysis of the results of the 63 coronary care units in Boston, Massachussets, USA, disclosed no perceptible fall in the hospital mortality from acute myocardial infarction between the years 1973-4 and 19789.1 This disappointing, if not unexpected, reality coupled with the fundamental influence of left ventricular function in determining the prognosis of patients with coronary heart disease ${ }^{23}$ gives great impetus to the search for measures to limit the extent of myocardial necrosis in patients with acute infarction. Many types of intervention can restrict the size of experimental infarctions, ${ }^{4}$ but of these the most rational and, therefore, the most attractive is the early restoration of antegrade blood flow. After acute coronary artery occlusion in the dog necrosis begins in the subendocardial region and spreads outwards towards the subepicardial layer; this "wavefront of necrosis" can be arrested by reperfusion. ${ }^{5}$ In 1960, Boucek and Murphy ${ }^{6}$ infused fibrinolysin into the aortic sinuses of patients with acute myocardial infarction and reported circumstantial evidence that the manoeuvre resulted in the re-establishment of blood flow. During the past five years the technique has been refined and applied to a large number of patients. In this issue of the journal, Cribier and his colleagues from Rouen ${ }^{7}$ add their experience to the already numerous published reports on the subject, and so it is opportune to examine the evidence for and against its acceptance as a new therapeutic option in the management of patients with acute myocardial infarction.

The reported studies have been remarkably consistent, both in their approach to the problem and in their results. They have confirmed the pathological observation that thrombotic occlusion of a coronary artery, usually but not invariably superimposed on a severe arteriosclerotic stenosis, is present in $80-95 \%$ of patients during the early hours after the onset of myocardial infarction..$^{8-10}$ Infusion of a fibrinolytic agent (streptokinase or streptokinase plus plasminogen) into the ostium of the coronary artery has been followed by restoration of patency in $64 \%^{11}$ to $95 \%^{12}$ of patients. The sooner treatment is commenced the greater its chance of process and the more rapidly thrombolysis is likely to occur, ${ }^{1011} 13$ and the rate of recanalisation may possibly be increased by a preliminary attempt to perforate the thrombus with a guide wire ${ }^{14}$ and by superselective infusion close to the site of occlusion. ${ }^{1215}$ Recanalisation does occur spontaneously. DeWood et al. ${ }^{16}$ observed coronary occlusion in $87 \%$ of patients undergoing angiography within four hours but in only $67 \%$ of those studied between 12 and 24 hours after the onset of infarction. When angiography was delayed for seven to 21 days, less than half of the patients were found to have occluded coronary arteries. ${ }^{17}$ It is clear from these figures, however, and confirmed by a small radomised controlled trial in which intracoronary streptokinase treatment was compared with a placebo infusion, ${ }^{18}$ that in most patients recanalisation during the procedure is effected by the fibrinolytic agent. Restoration of blood flow has usually been accompanied by resolution of chest pain, by a return of the electrocardiographic ST segments towards the isoelectric line, by an early peak of the serum creatine phosphokinase activity, and in many cases by the occurence of a variety of ventricular tachyarrhythmias or by bradycardia or atrioventricular block. Patients in whom recanalisation has been accomplished within about four hours of the onset of their symptoms have shown evidence of improved regional, and usually global, left ventricular function compared with patients in whom recanalisation did not occur or with those in whom a longer period of time had lapsed between the onset of chest pain and the restoration of blood flow. Two recent randomised controlled trials appear to confirm the results of these uncontrolled observations. In the first, ${ }^{18}$ the average time between the onset of chest pain and the start of the streptokinase infusion was over five hours and no difference in left ventricular function was observed between patients receiving 
treatment and those receiving placebo, either before or after the infusion. In the second trial ${ }^{24}$ streptokinas treatment was started within three hours in most of the patients, and left ventricular function improved substantially between the first and tenth days in comparison with the control group, who were managed conservatively. Coupled with the improved thallium201 uptake by the ischaemic region which has been shown after early recanalisation,,$^{212325}$ and by the association of secondary reocclusion with reinfarction, ${ }^{1426}$ these observations strongly " suggest that thrombolysis can prevent part of the jeopardised myocardium from becoming infarcted. Nevertheless, some degree of myocardial necrosis, evident from enzyme release and the loss of $R$ waves on the electrocardiogram, is almost invariable. The time course of the necrosis, and thus the potential for myocardial salvage from reperfusion, is impossible to predict in an individual case, and probably depends on several factors including the metabolic requirements of the myocardium and the efficiency of the collateral circulation. ${ }^{1923}$

The clinical results of thrombolysis have been encouraging. In the German multicentre study mortality was $7 \%$ among patients in whom reperfusion occurred and $24 \%$ among those in whom the occlusion persisted ${ }^{26}$ and there have been isolated reports of the cardiogenic shock after successful recanalisation. ${ }^{13}$

Complications during the procedure have been frequent, ${ }^{11}$ and occasionally fatal. It is, of course, often difficult to judge whether a complication arose as a direct result of the intervention or from the infarction itself. Haemorrhage has been common but rarely life threatening, has usually been related to a pre-existing cause (such as recent surgery or the arteriotomy required for angiography), and has occurred most frequently when a large total dose of streptokinase has reduced the serum fibrinogen concentration to less than $1 \mathrm{~g} / \mathrm{l}(2.94 \mu \mathrm{mol} / \mathrm{l}){ }^{20}$ Disturbances of cardiac rhythm, as a result of the cardiac catheterisation and angiography, or of the reperfusion itself, have usually been managed without difficulty, though fatal asystole has followed the injection of ionic contrast medium into an unoccluded right coronary artery, ${ }^{11}$ and ventricular tachycardia after reperfusion has often been recurrent. Haemorrhagic infarction, a result of ischaemic vascular damage, has been reported in fatal cases $^{27}$ and may be common among survivors, but despite the results of animal experiments which have raised the worrying possibility that haemorrhage after reperfusion might increase the size of the infarction ${ }^{28}$ there is as yet no evidence that this occurrence has been directly responsible for an unfavourable outcome in man. The most worrying complications are those which have caused the death of a patient who might otherwise have been expected to survive. Ser- ruys et al. ${ }^{11}$ reported two patients in whom a thrombus was dislodged from the left anterior descending artery and embolised into the circumflex artery with fatal consequences.

The experience of the Rouen group ${ }^{7}$ does not differ appreciably from these combined results of earlier investigators, and since they adopted a similar approach - namely, an attempt at recanalisation in all patients followed by a comparison of those in whom it was successful with those in whom the coronary occlusion persisted-it would have been optimistic to expect any profound new insight. The evidence of improved left ventricular function resulting from early recanalisation is compelling, though it should perhaps be pointed out that the assessment of left ventricular function was not carried out without knowledge of the success or failure of the attempted thrombolysis. The authors raise the possibility that recanalisation followed by reocclusion is better, in terms of left ventricular function, than no recanalisation at all, but the numbers are too small for firm conclusions to be drawn from them.

We do not know whether the thrombolytic treatment improves prognosis. Although mortality has been lower among patients in whom it was successful than among those in whom it was not, ${ }^{71426}$ the two groups of patients may not have been comparable, and it is possible that patients with a good prognosis with conventional management are also those in whom reperfusion can most easily be achieved. This notion, though it may seem improbable and would be difficult to explain, gains some support from the Rouen experience in which recanalisation was effected in only four out of 12 patients with cardiogenic shock. ${ }^{7}$ Quite apart from problems related to the procedure it is certainly possible that myocardial salvage may itself be the origin of further complications, with ischaemic but viable myocardium acting as a substrate for the development of re-entry arrhythmias and with the potential for subsequent completion of the infarction should reocclusion occur.

Thus despite the encouraging results we do not know whether the procedure offers the prospect of lasting benefit to the patient, and this poses a dilemma for doctors working in hospitals in which the facilities and expertise are available. In the light of existing knowledge intracoronary thrombolysis should probably be attempted only in patients in whom there is least to lose and most to gain: those who arrive in hospital with continuing pain of less than three hours' duration, with evidence of extensive ischaemia, and in whom the circulation is deteriorating. While there is little doubt that serious complications from angiography are most likely to occur in the presence of hypotension, these can be minimised by the avoidance of left ventriculography and by the use of a non-ionic 
contrast medium for the essential minimum of coronary artery injections. ${ }^{11}$ Apart from in such carefully selected patients there can be little justification for attempting thrombolysis except as part of a randomised controlled trial, the end point of which is mortality.

A number of such trials are in progress, and an indication of their importance is given by the preliminary, but essentially negative, results of the Rotterdam trial. ${ }^{29} 30$ The questions these trials seek to answer, however, are elementary compared with those which will be posed by their results. If "positive," should all district hospitals be equipped with facilities for emergency coronary arteriography? Should we make renewed efforts to set up a more extensive coronary ambulance service in order to reach patients earlier? This second proposal, at least, could be justified on other grounds. If "negative," then should the procedure be combined with aortocoronary bypass grafting, ${ }^{32}$ or with angioplasty?, ${ }^{32}$ or should we try to define more accurately which patients are most likely to benefit? The complexity of these issues is such that it is difficult to imagine how they could be resolved by a conventional trial.

To the sceptical it must be conceded that even if the current trials show clear evidence of improved survival it is unlikely, for logistic reasons if none other, that the technique will make a major impact on the mortality from acute myocardial infarction in the community as a whole. This should not, however, be used as an argument against the use of resources to resolve the issues, because intracoronary thrombolysis has become available and guidance is required for the individual doctor who is faced with an individual patient. It seems quite possible that many of these considerations will become irrelevant if the efficacy of systomic fibrinolysis can be confirmed ${ }^{33} 34$; intravenous administration has the great advantages that it could be carried out in any coronary care unit (and could perhaps be initiated even by the family doctor), it avoids the hazards and delays inherent in emergency coronary arteriography, and its use would be immeasurably less demanding of limited resources.

\section{References}

1 Goldman L, Cook F, Hashimoto B, Stone P, Muller J, Loscalzo A. Evidence that hospital care for acute myocardial infarction has not contributed to the decline in coronary mortality between 1973-74 and 1978-79. Circulation 1982; 65: 936-42.

2 Bruschke AVG, Proudfit WL, Sones FM Jr. Progress study of 590 consecutive non-surgical cases of coronary disease followed 5-9 years. II Ventriculographic and other correlations. Circulation 1973; 47: 1154-63.

3 Hammermeister KE, De Rouen TA, Dodge HT. Variables predictive of survival in patients with coronary disease. Selection by univariate and multivariate analysis from the clinical, electrocardiographic, exercise, arteriographic, and quantitative angiographic evaluations. Circulation 1979; 59: 421-35.

4 Maroko PR, Braunwald E. Modification of myocardial infarction size after coronary occlusion. Ann Intern Med 1973; 79: 720-33.

5 Reimer KA, Lowe JE, Rasmussem MM, Jennings RB. The wavefront phenomenon of ischemic cell death. 1 . Myocardial infarct size vs. duration of coronary occlusion in dogs. Circulation 1977; 56: 786-94.

6 Boucek RJ, Murphy WP Jr. Segmental perfusic'.l of the coronary arteries with fibrinolysin in man following a myocardial infarction. Am f Cardiol 1960; 6: 525-33.

7 Cribier A, Berland J, Champoud O, Moore N, Behar P, Letac B. Intracoronary thrombolysis in evolving myocardial infarction. Sequential angiographic analysis of left ventricular performance. Br Heart $\mathcal{F}$ 1983; 50: 401-10.

8 Davies MJ, Woolf N, Robertson WB. Pathology of acute myocardial infarction with particular reference to occlusive coronary thrombi. Br Heart $\mathcal{f}$ 1976; 38: 659-64.

9 Horie T, Sekiguchi M, Hirosawa K. Coronary thrombosis in pathogenesis of acute myocardial infarction. $\mathrm{Br}$ Heart f 1978; 40: 153-61.

10 Rutsch W, Schartl M, Mathey D, et al. Percutaneous transluminal coronary recanalization: procedure, results, and acute complications. Am Heart $\mathcal{F}$ 1981; 102: 117881.

11 Serruys PW, van den Brand M, Hooghoudt TEH, et al. Coronary recanalization in acute myocardial infarction: immediate results and potential risks. Eur Heart $\mathcal{F}$ 1982; 3: 404-15.

12 Ganz W, Buchbinder N, Marcus $\mathrm{H}$ et al. Intracoronary thrombolysis in evolving myocardial infarction. Am Heart $f$ 1981; 101: 4-13.

13 Lee G, Amsterdam EA, Low R, et al. Efficacy of percutaneous transluminal coronary recanalization utilizing streptokinase thrombolysis in patients with acute myocardial infarction. Am Heart $\mathcal{f}$ 1981; 102: 1159-67.

14 Mathey DG, Kuck K-H, Tilsner V, Krebber HJ, Bleifeld W. Non-surgical coronary artery recanalisation in acute transmural myocardial infarction. Circulation 1981; 63: 489-97.

15 Ganz W, Geft I, Maddahi J, et al. Nonsurgical reperfusion in evolving myocardiai infarction. $\mathcal{F}$ Am Coll Cardiol 1983; 1: 1247-53.

16 DeWood MA, Spores J, Notske RN, et al. Prevalence of total coronary occlusion during the early hours of transmural myocardial infarction. $N$ Engl f Med 1980; 303: 897-902.

17 Bertrand ME, Lefebvre JM, Laisne CL, Rousseau MF, Carre AG, Lekieffre JP. Coronary arteriography in acute transmural myocardial infarction. Am Heart f 1979; 97: 61-9.

18 Khaja F, Walton JA Jr, Brymer JF, et al. Intracoronary fibrinolytic therapy in acute myocardial infarction. Report of a prospective randomised trial. $N$ Engl $\mathcal{F}$ Med 1983; 308: 1305-11.

19 Rentrop P, Blanke H, Karsch KR, et al. Changes in left ventricular function after intracoronary streptokinase infusion in clinically evolving myocardial infarction. $A m$ Heart F 1981; 102: 1188-93. 
20 Cowley MJ, Hastillo A, Vetrovec GW, Hess ML. Effects of intracoronary streptokinase in acute myocardial infarction. Am Heart f 1981; 102: 1149-58.

21 Reduto LA, Freund GC, Gaeta JM, et al. Coronary artery reperfusion in acute myocardial infarction: beneficial effects of intracoronary streptokinase on left ventricular salvage and performance. Am Heart f 1981; 102: 1168-77.

22 Hooghoudt TEH, Serruys PW, Reiber JHC, et al. The effect of recanalization of the occluded coronary artery in acute myocardial infarction on left ventricular function. Eur Heart f 1982; 3: 416-21.

23 Schwartz F, Schuler G, Katus H, et al. Intracoronary thrombolysis in acute myocardial infarction; correlations among serum enzyme, scintigraphic and hemodynamic findings. Am $\mathcal{F}$ Cardiol 1982; 50: 32-8.

24 Anderson JL, Marshall HW, Bray BE, et al. A randomized trial of intracoronary streptokinase in the treatment of acute myocardial infarction. $N$ Engl F Med 1983; 308: 1312-8.

25 Markis JE, Malagold M, Parker JA, et al. Myocardial salvage after intracoronary thrombolysis with streptokinase in acute myocardial infarction. Assessment by intracoronary Thallium-201. $N$ Engl f Med 1981; 305: 777-82.

26 Merx W, Dörr R, Rentrop P, et al. Evaluation of the effectiveness of intracoronary streptokinase infusion in acute myocardial infarction: post-procedure management and hospital course in 204 patients. Am Heart $\mathcal{F}$ 1981; 102: 1181-7.

27 Mathey DG, Schofer J, Kuck K-H, Beil U, Klöppel G. Transmural, haemorrhagic myocardial infarction after intracoronary streptokinase. Clinical, angiographic, and necropsy findings. Br Heart f 1982; 48: 546-51.

28 Bresnahan GF, Roberts R, Shell WE, Ross J Jr, Sobel
BE. Deleterious effects due to hemorrhage after myocardial reperfusion. Am $\mathcal{F}$ Cardiol 1974; 33: 82-6.

29 Fioretti P, Simoons ML, Serruys PW, van den Brand M, Fels PW, Hugenholz P. Clinical course after attempted thrombolysis in myocardial infarction. Results of pilot studies and preliminary data from a randomized trial. Eur Heart F 1982, 3: 422-32.

30 Simoons ML, Wijns W, Balakumaran K, et al. The effect of intracoronary thrombolysis with streptokinase on myocardial thallium distribution and left ventricular function assessed by blood-pool scintigraphy. Eur Heart f 1982; 3: 433-40.

31 Mathey DG, Rodewald G, Rentrop P, et al. Intracoronary streptokinase thrombolytic recanalisation and subsequent surgical bypass of remaining atherosclerotic stenosis in acute myocardial infarction: complementary combined approach effecting reduced infarct size, preventing reinfarction, and improving left ventricular function. Am Heart f 1981; 102: 1194-201.

32 Meyer J, Merx W, Schmitz H, et al. Percutaneous transluminal coronary angioplasty immediately after intracoronary streptolysis of transmural myocardial infarction. Circulation 1982; 66: 905-13.

33 Schröder R, Biamino G, Leitner ER, et al. Intravenous short-term infusion of streptokinase in acute myocardial infarction. Circulation 1983; 67: 536-48.

34 European cooperative study group for streptokinase treatment in acute myocardial infarction. Streptokinase in acute myocardial infarction. $N$ Engl F Med 1979; 301: 797-802.

Requests for reprints to Dr Nicholas Brooks, Cardiac Department, London Chest Hospital, Bonner Road, London E2 9JX 